\title{
Impact of eIF4E phosphorylation at Ser209 via MNK2a on tumour recurrence after curative surgery in localized clear cell renal cell carcinoma
}

\author{
Osamu Ichiyanagi ${ }^{1,2, *}$, Hiromi Ito ${ }^{1, *}$, Sei Naito ${ }^{1, *}$, Takanobu Kabasawa $^{3}$, Hidenori \\ Kanno ${ }^{1}$, Takafumi Narisawa ${ }^{1}$, Masaki Ushijima ${ }^{1}$, Yuta Kurota ${ }^{1}$, Michinobu Ozawa ${ }^{1}$, \\ Toshihiko Sakurai ${ }^{1}$, Hayato Nishida ${ }^{1}$, Tomoyuki Kato ${ }^{1}$, Mitsunori Yamakawa ${ }^{3}$, and \\ Norihiko Tsuchiya ${ }^{1}$ \\ ${ }^{1}$ Department of Urology, Yamagata University Faculty of Medicine, Yamagata, Japan \\ ${ }^{2}$ Department of Urology, Yamagata Prefectural Kahoku Hospital, Kahoku, Japan \\ ${ }^{3}$ Department of Pathological Diagnostics, Yamagata University Faculty of Medicine, Yamagata, Japan \\ *These authors contributed equally to this work \\ Correspondence to: Sei Naito, email: seinaitoh@yahoo.co.jp \\ Keywords: renal cell carcinoma; phospho-elF4E (p-elF4E); MNK (MAPK-interacting kinase); recurrence-free; epithelial- \\ mesenchymal transition \\ Received: February 01, $2019 \quad$ Accepted: May 20, $2019 \quad$ Published: June 18, 2019 \\ Copyright: Ichiyanagi et al. This is an open-access article distributed under the terms of the Creative Commons Attribution License \\ 3.0 (CC BY 3.0), which permits unrestricted use, distribution, and reproduction in any medium, provided the original author and \\ source are credited.
}

\section{ABSTRACT}

Background: We investigated the roles of eIF4E phosphorylation (Ser209) in tumour recurrence after curative nephrectomy for localized clear cell renal cell carcinoma (CcRCC).

Methods: Expression of eIF4E, $p$ eIF4E and MNKs (MAPK interacting kinases), was evaluated in surgical specimens obtained from consecutive non metastatic cCRCC patients ( $n=290$ ) by immunohistochemistry (IHC), immunoblotting, and qRT PCR at the protein and mRNA levels. In human RCC cell lines, the effects of eIF4E phosphorylation were examined using immunoblotting, proliferation, migration and invasion assays with pharmacological inhibitors (CGP57380 or ETP45835) and specific small interfering (si) RNAs against MNK1/2(a/b).

Results: In postoperative follow-up (median, 7.9 y), 40 patients experienced metastatic recurrence. In multivariate Cox analyses, higher IHC expression of $p$ eIF4E in cCRCC significantly predicted a longer recurrence-free interval. eIF4E is phosphorylated mainly by MNK2a in tumour specimens and cell lines. In 786-O and A-498 cell lines, pharmacological inhibition of MNKs decreased p-eIF4E and increased vimentin and $\mathbf{N}$ cadherin but did not influence proliferation. Similarly, MNK2 or MNK2a inhibition with siRNA reduced p-eIF4E and enhanced vimentin translation, cell migration and invasion in the cell lines.

Conclusions: MNK2a-induced eIF4E phosphorylation may suppress metastatic recurrence of $\mathrm{CCRCC}$, partially due to vimentin downregulation at the translational level, consequently leading to inhibition of epithelial-mesenchymal transition.

\section{INTRODUCTION}

Renal cell carcinoma (RCC) is one of the most common malignant tumours originating in the kidney. Clear cell histology consists of approximately $80 \%$ of RCC [1,2]. The incidence and mortality rates of $\mathrm{RCC}$ are increasing all over the world including Japan $[1,2]$. An estimated $20 \%-30 \%$ of patients presented with metastatic disease during initial diagnosis $[1,2]$. The survival rates for metastatic RCC have been drastically 
improved owing to the development of targeted drugs and immune checkpoint inhibitors [3]. However, the prognosis of patients with advanced-stage (T3-4, N+, $\mathrm{M}+) \mathrm{RCC}$ remains extremely poor, with a 5-year overall survival (OS) rate of $10 \%-30 \%$ [1]. In contrast, the 5 -year recurrence-free and overall survival rates of RCC at stage I were around $95 \%$, respectively [1]. Up to $30 \%$ of patients who undergo curative surgery for clinically-confined RCC suffer from disease recurrence [4].

The translation initiation factor eukaryotic initiation factor (eIF) 4E plays a pivotal role in protein biosynthesis at a subcellular level [5]. eIF4E is released from eIF4Ebinding protein 1 (4EBP1) that is phosphorylated by activation of mammalian target of rapamycin complex 1 (mTORC1). eIF4E is the rate-limiting component in binding and cap-dependent translation of certain mRNAs. In normal cells, mRNA and protein expression of eIF4E are regulated at relatively low levels and eIF4E expression and activity depends upon various signals and stresses from outside the cells [5]. In malignant cells, eIF4E is overexpressed to promote neoplastic transformation and tumorigenesis $[5,6]$. eIF4E is persistently hyperactivated due to genetic alterations of pathway components located upstream of the 4EBP1/eIF4E axis, as the genes encoding 4EBP1 and eIF4E remain normal in the vast majority of cancers, including RCC $[5,7,8]$.

Interacting with the scaffold eIF4G, eIF4E is phosphorylated at Ser209 by mitogen-activated protein kinase (MAPK) -interacting kinase 1/2 (MNK1/2) [9]. Human MNK1/2 are encoded by two different genes, $M K N K 1$ and $M K N K 2$. The transcripts of MKNK1 and $M K N K 2$ can be alternatively spliced, giving rise to two proteins, MNK1a/2a (the longer forms) and MNK1b/2b (the shorter forms) with functional differences in their $\mathrm{N}$ - and C-terminal regions [9]. No difference in the ability to phosphorylate eIF4E has been reported among $\mathrm{MNK} 1 / 2 / \mathrm{a} / \mathrm{b}$ isoforms [9]. However, the oncological roles of p-eIF4E in malignancies are not completely understood [10]. Herein, we aim to investigate: (1) the clinical relevance of $\mathrm{p}$-eIF4E in predicting tumour recurrence after curable resection of localized ccRCC, and (2) the effects of p-eIF4E on tumour behaviours by inhibiting MNKs in $\mathrm{RCC}$ cell lines.

\section{RESULTS}

\section{Clinicopathological backgrounds of ccRCC patients}

Consecutive patients $(n=290)$ who underwent curative surgery for localized ccRCC were recruited in the present study. The median follow-up duration was 7.9 years $(0.02-19.9$ years $)$ after radical $(n=186)$ or partial ( $n=104)$ nephrectomy. Surgical approaches used were open $(n=178)$ or laparoscopic $(n=112)$. Patient demographics are summarised in Table 1 . In the course of postoperative follow-up, forty patients experienced cancer recurrence in the lung, lymph nodes, liver, bone, adrenal glands, and other sites $(n=25,10,5,5,2$, and 7 , respectively). Local recurrence occurred in two cases. Eight patients presented with recurrent lesions in multiple organs. Of patients who had a recurrence, 21 died of ccRCC in the follow-up period.

The potential clinical significance of eIF4E and p-eIF4E expression in the study cohorts is also presented in Table 1. eIF4E was expressed at significantly higher levels in patients with ccRCC recurrence than those without ( $p=0.032)$. However, expression levels of eIF4E protein in ccRCC were comparable in different conditions of pT stage, lymph nodes, Fuhrman grade, sarcomatoid differentiation, coagulative necrosis, and microvascular invasion (MVI) (not significant for all). In contrast, peIF4E expression in ccRCC was significantly lower in the recurrent patients than in the recurrence-free patients $(p=0.040)$. The expression levels of $\mathrm{p}$-eIF4E protein significantly differed in $\mathrm{pT}$ stage and $\mathrm{pN}(p<0.001$ and $p=0.030$, respectively), whereas $\mathrm{p}$-eIF4E protein was expressed at comparable levels in tumours of different Fuhrman grade, sarcomatoid differentiation, coagulative necrosis, and MVI. High eIF4E and low p-eIF4E expression was marginally associated with cancer-specific survival (CSS) ( $p=0.105$ and 0.114 , respectively) but not with OS (Table 1).

In Kaplan-Meier survival analysis, the recurrencefree and CSS rates were significantly poorer as tumours progressed into advanced conditions of $\mathrm{pT}$ stages (pT1a, $1 \mathrm{~b}, 2,3$ or 4$), \mathrm{pN}$ ( $\mathrm{pN} 0 / \mathrm{X}$ or 1$)$, Fuhrman grade $(1,2$, 3 or 4 ), sarcomatoid differentiation (absent or present), coagulative necrosis (absent or present), and MVI (positive or negative) for the entire cohort ( $p<0.001$ for each, respectively, log-rank test; Supplementary Tables 1 and 2, and Supplementary Figures 2 and 3). The recurrence-free and CSS intervals were significantly shorter in patients who presented with high eIF4E expression than those with low expression ( $(p<0.05$ for both, log-rank test; Figure $1 \mathrm{~B}$ and $1 \mathrm{C})$. In contrast, the recurrence-free interval (RFI) was significantly longer in patients who presented with high p-eIF4E expression than in those who did not $(p<0.05$, log-rank test; Figure 1D), but Kaplan-Meier curves for CSS differed marginally between those with high and low peIF4E expression ( $p=0.084$, log-rank test; Figure 1E). In univariate and multivariate (model 1) Cox regression analyses (Table 2 ), pT1b $\leq$ stage (vs. pT1a), Fuhrman grade $3 / 4$ (vs. grade 1/2), presence of coagulative necrosis (vs. absence), and high eIF4E expression (vs. low) were significantly related to a high risk of recurrence and cancer-specific mortality. However, expression levels of p-eIF4E (high vs. low) were independent factors for predicting recurrence-free status but not for CSS (Table 2).

The combination of eIF4E (high vs. low) and p-eIF4E (high vs. low) expression levels significantly stratified Kaplan-Meier curves for recurrence-free status 
Table 1: Clinicopathological backgrounds of study patients, and associations with eIF4E and p-eIF4E expression

\begin{tabular}{|c|c|c|c|c|c|c|c|c|}
\hline \multirow{2}{*}{ Factors } & & \multirow{2}{*}{ All patients } & \multicolumn{3}{|c|}{ eIF4E expression } & \multicolumn{3}{|c|}{ p-eIF4E(S209) expression } \\
\hline & & & Low & High & $\boldsymbol{P}$ & Low & High & $P$ \\
\hline $\begin{array}{l}\text { Number of } \\
\text { patients }\end{array}$ & & 290 & 104 & 186 & & 142 & 148 & \\
\hline $\begin{array}{l}\text { Age at } \\
\text { nephrectomy, } \\
\text { years }\end{array}$ & $\begin{array}{l}\text { Mean } \pm \\
\text { SD } \\
\text { [range] }\end{array}$ & $\begin{array}{c}62.8 \pm 11.6 \\
{[28-85]}\end{array}$ & $\begin{array}{c}63.5 \pm 11.6 \\
{[30-83]}\end{array}$ & $\begin{array}{c}62.4 \pm 11.6 \\
{[28-85]}\end{array}$ & $0.437^{\natural}$ & $\begin{array}{c}63.0 \pm 11.6 \\
{[28-83]}\end{array}$ & $\begin{array}{c}62.6 \pm 11.6 \\
{[34-85]}\end{array}$ & $0.801^{\Uparrow}$ \\
\hline \multirow[t]{2}{*}{ Sex } & Male & $192(66.2)$ & $68(65.4)$ & $124(66.7)$ & $0.897^{\#}$ & $92(64.8)$ & $100(67.6)$ & $0.622^{\#}$ \\
\hline & Female & $98(33.8)$ & $36(34.6)$ & $62(33.3)$ & & $50(35.2)$ & $48(32.4)$ & \\
\hline \multirow[t]{2}{*}{ Tumour laterality } & Left & $136(46.9)$ & $52(50.0)$ & $84(45.2)$ & $0.463^{\#}$ & $72(50.7)$ & $64(43.2)$ & $0.239^{\#}$ \\
\hline & Right & $154(53.1)$ & $52(50.0)$ & $102(54.8)$ & & $70(49.3)$ & $84(56.8)$ & \\
\hline \multirow[t]{5}{*}{$\begin{array}{l}\text { Pathological T } \\
\text { stage }\end{array}$} & pT1a & $169(58.3)$ & $61(58.7)$ & $108(58.1)$ & $0.692^{\S}$ & $71(50.0)$ & $98(66.2)$ & $<0.001^{\S}$ \\
\hline & $\mathrm{pT} 1 \mathrm{~b}$ & $58(20.0)$ & $21(20.2)$ & $37(19.9)$ & & $42(29.6)$ & $16(10.8)$ & \\
\hline & pT2 & $19(6.6)$ & $9(8.7)$ & $10(5.4)$ & & $6(4.2)$ & $13(8.8)$ & \\
\hline & pT3 & $42(14.5)$ & $13(12.5)$ & $29(15.6)$ & & $22(15.5)$ & $20(13.5)$ & \\
\hline & pT4 & $2(0.7)$ & $0(0.0)$ & $2(1.1)$ & & $1(0.7)$ & $1(0.7)$ & \\
\hline \multirow[t]{2}{*}{$\begin{array}{l}\text { Pathological N } \\
\text { stage }\end{array}$} & $\mathrm{pN} 0 / \mathrm{NX}$ & 284 (97.9) & $103(99.0)$ & $181(97.3)$ & $0.425^{\S}$ & $142(100.0)$ & $142(95.9)$ & $0.030^{\S}$ \\
\hline & $\mathrm{pN} 1$ & $6(2.1)$ & $1(1.0)$ & $5(2.7)$ & & $0(0.0)$ & $6(4.1)$ & \\
\hline \multirow[t]{4}{*}{ Fuhrman grade } & G1 & 115 (39.7) & $48(46.2)$ & $67(36.0)$ & $0.255^{\S}$ & $61(43.0)$ & $54(36.5)$ & $0.614^{\S}$ \\
\hline & $\mathrm{G} 2$ & $120(41.4)$ & $40(38.5)$ & $80(43.0)$ & & $57(40.1)$ & $63(42.6)$ & \\
\hline & G3 & $39(13.4)$ & $13(12.5)$ & $26(14.0)$ & & $18(12.7)$ & $21(14.2)$ & \\
\hline & G4 & $16(5.5)$ & $3(2.9)$ & $13(7.0)$ & & $6(4.2)$ & $10(6.8)$ & \\
\hline \multirow[t]{2}{*}{$\begin{array}{l}\text { Sarcomatoid } \\
\text { differentiation }\end{array}$} & Absent & 278 (95.9) & 99 (95.2) & $179(96.2)$ & $0.761^{\S}$ & $137(96.5)$ & $141(95.3)$ & $0.770^{\S}$ \\
\hline & Present & $12(4.1)$ & $5(4.8)$ & $7(3.8)$ & & $5(3.5)$ & $7(4.7)$ & \\
\hline \multirow[t]{2}{*}{$\begin{array}{l}\text { Coagulative } \\
\text { necrosis }\end{array}$} & Absent & $248(85.5)$ & 88 (84.6) & $160(86.0)$ & $0.732^{\#}$ & $120(84.5)$ & $128(86.5)$ & $0.739^{\#}$ \\
\hline & Present & $42(14.5)$ & $16(15.4)$ & $26(14.0)$ & & $22(15.5)$ & $20(13.5)$ & \\
\hline \multirow[t]{2}{*}{$\begin{array}{l}\text { Microvascular } \\
\text { invasion }\end{array}$} & Negative & 252 (86.9) & $90(86.5)$ & $162(87.1)$ & $1.000^{\#}$ & $119(83.8)$ & $133(89.9)$ & $0.163^{\#}$ \\
\hline & Positive & $38(13.1)$ & $14(13.5)$ & $24(12.9)$ & & $23(16.2)$ & $15(10.1)$ & \\
\hline \multicolumn{9}{|l|}{ Events } \\
\hline \multirow[t]{2}{*}{ Recurrence } & No & $250(86.2)$ & $96(92.3)$ & $154(82.8)$ & $0.032^{\#}$ & $116(81.7)$ & $134(90.5)$ & $0.040^{\#}$ \\
\hline & Yes & $40(13.8)$ & $8(7.7)$ & $32(17.2)$ & & $26(18.3)$ & $14(9.5)$ & \\
\hline \multirow[t]{2}{*}{$\begin{array}{l}\text { Cancer- } \\
\text { specific } \\
\text { survival }\end{array}$} & Alive & $269(92.8)$ & $100(96.2)$ & $169(90.9)$ & $0.105^{\S}$ & $128(90.1)$ & $141(95.3)$ & $0.114^{\S}$ \\
\hline & Dead & $21(7.2)$ & $4(3.8)$ & $17(9.1)$ & & $14(9.9)$ & $7(4.7)$ & \\
\hline \multirow[t]{2}{*}{$\begin{array}{l}\text { Overall } \\
\text { survival }\end{array}$} & Alive & $236(81.4)$ & $87(83.7)$ & $149(80.1)$ & $0.530^{\#}$ & 113 (79.6) & $123(83.1)$ & $0.455^{\#}$ \\
\hline & Dead & $54(18.6)$ & $17(16.3)$ & 37 (19.9) & & $29(20.4)$ & $25(16.9)$ & \\
\hline Follow-up & $\begin{array}{l}\text { Years } \\
\text { (IQR) }\end{array}$ & $\begin{array}{c}7.85 \\
(6.08-10.62)\end{array}$ & $\begin{array}{l}8.95 \\
(6.85- \\
11.73)\end{array}$ & $\begin{array}{c}7.11 \\
(5.93-9.84)\end{array}$ & $<0.001^{\square}$ & $\begin{array}{c}7.50 \\
(6.06-10.39)\end{array}$ & $\begin{array}{c}8.18 \\
(6.14-10.80)\end{array}$ & $0.429^{\square}$ \\
\hline
\end{tabular}

Abbreviations: eIF4E; eukaryonic translation initiation factor 4E, p-eIF4E; phospho-eIF4E, SD; standard distribution, IQR; interquantile range, "; Chi-square test, ${ }^{\S}$; Fisher's exact test, `; Student’s $t$-test, and $\square$; Mann-Whitney's $U$ test in comparison between groups with low and high expression of each protein. Values are presented as numbers (\%) unless specifically indicated. 
A

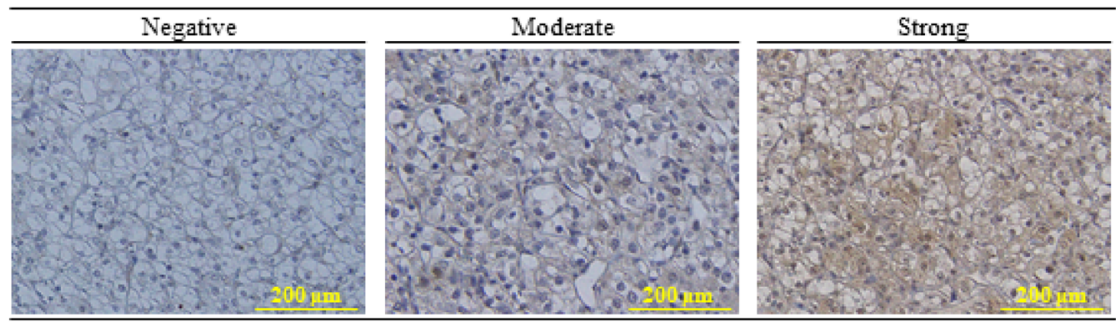

B

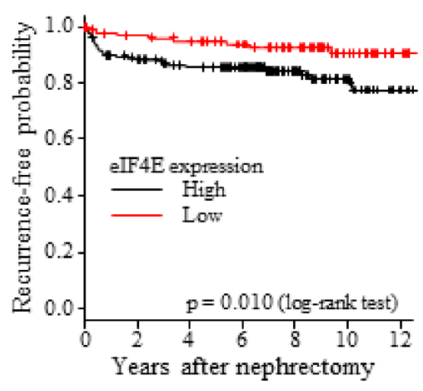

Number at risk

$\begin{array}{llllllll}\text { High } & 186 & 155 & 141 & 127 & 71 & 41 & 16\end{array}$

$\begin{array}{llllllll}\text { Low } & 104 & 96 & 92 & 82 & 61 & 38 & 23\end{array}$

D

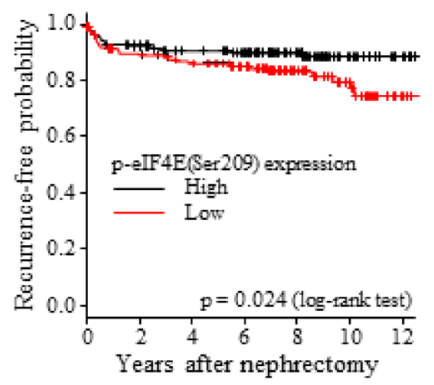

Number at risk

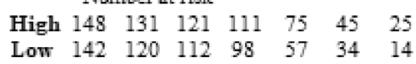

$\mathbf{F}$

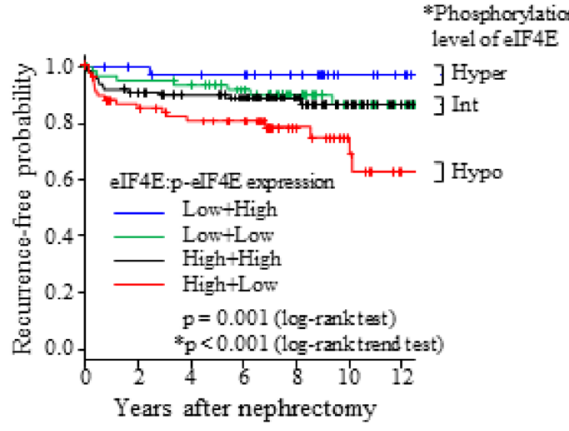

Number at risk

$\begin{array}{llllllr}\text { Low+High 38 } & 35 & 33 & 32 & 26 & 17 & 14 \\ \text { Low+Low 66 } & 61 & 59 & 50 & 35 & 21 & 9 \\ \text { High+Highl110 } & 96 & 88 & 79 & 49 & 28 & 11 \\ \text { High+Low 76 } & 59 & 53 & 48 & 22 & 13 & 5\end{array}$
C

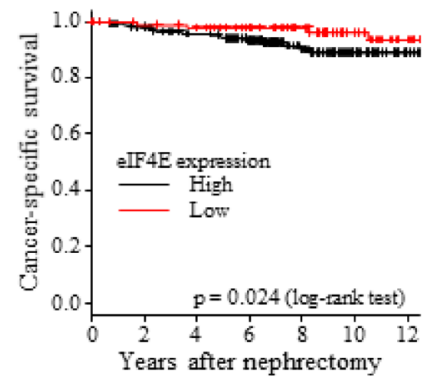

Number at risk

$\begin{array}{llllllll}\text { High } & 186 & 171 & 155 & 136 & 76 & 44 & 19\end{array}$

E

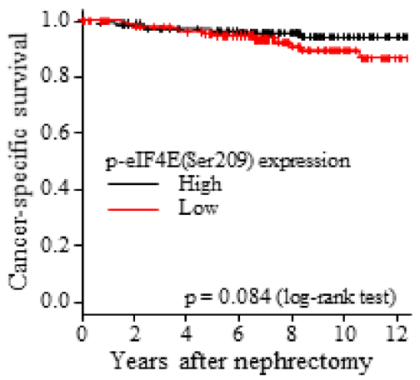

Number at risk

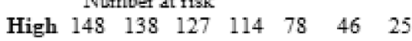

$\begin{array}{llllllll}\text { Low } & 142 & 131 & 123 & 107 & 62 & 39 & 19\end{array}$

G

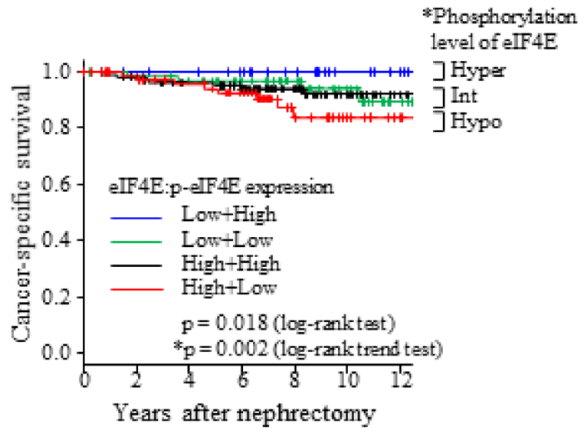

Number at risk

$\begin{array}{lllllll}\text { Low+High 38 } & 35 & 34 & 32 & 26 & 17 & 14 \\ \text { Low+Low 66 } & 63 & 61 & 53 & 38 & 24 & 11 \\ \text { High+Highl 10 } & 103 & 93 & 82 & 52 & 29 & 11 \\ \text { High+Low 76 } & 68 & 62 & 54 & 24 & 15 & 8\end{array}$

Figure 1: Grading of eIF4E and p-eIF4E(Ser209) expression levels by IHC semi-quantitation and their impact on recurrence-free and CSS intervals. (A) The representative panels of IHC intensity are shown. The panels were used to grade eIF4E and p-eIF4E expression in ccRCC specimens obtained by curative nephrectomy. The photos in these panels show p-eIF4E IHC (scale bars = $200 \mu \mathrm{m}$, original magnification 200×). IHC data were analysed as described in the Materials and Methods section. Kaplan-Meier curves for recurrence-free and CSS rates in the entire study cohort were stratified with high and low levels of eIF4E (B, C), p-eIF4E (D, E) expression, and a combination of eIF4E with p-eIF4E IHC stainability $(\mathbf{F}, \mathbf{G})$ in ccRCC tissues, respectively. The definition of phosphorylation levels of eIF4E (F, G) was presented in the Materials and Methods. "The trends among hypo-, intermediate and hyper-phosphorylation levels of eIF4E were evaluated with log-rank trend tests (F, G). 
Table 2: Effects of clinicopathological factors on prognosis of ccRCC using Cox' proportional hazard analysis

\begin{tabular}{|c|c|c|c|c|c|c|c|c|c|c|c|}
\hline \multirow{2}{*}{ Factors } & \multicolumn{2}{|c|}{ Risk category } & \multicolumn{3}{|c|}{ Univariate } & \multicolumn{3}{|c|}{ Multivariate (model 1) } & \multicolumn{3}{|c|}{ Multivariate (model 2) } \\
\hline & 1 (ref.) & & HR & $95 \% \mathrm{CI}$ & $p$ & HR & $95 \%$ CI & $p$ & HR & $95 \% \mathrm{CI}$ & $p$ \\
\hline \multicolumn{12}{|l|}{ Recurrence-free interval } \\
\hline Pathological T stage & pTa & $\mathrm{pT} 1 \mathrm{~b} \leq$ & 20.16 & $6.21-65.44$ & $<0.001$ & 8.46 & $2.47-29.02$ & $<0.001$ & 7.99 & $2.33-27.37$ & $<0.001$ \\
\hline Pathological N stage & $\mathrm{pN} 0 / \mathrm{X}$ & $\mathrm{pN} 1$ & 8.13 & $2.50-26.45$ & $<0.001$ & - & - & NS & - & - & NS \\
\hline Fuhrman grade & $\mathrm{G} 1 / 2$ & $\mathrm{G} 3 / 4$ & 7.84 & $4.17-14.71$ & $<0.001$ & 3.58 & $1.78-7.21$ & $<0.001$ & 3.47 & $1.71-7.04$ & $<0.001$ \\
\hline $\begin{array}{l}\text { Sarcomatoid } \\
\text { differentiation }\end{array}$ & Absent & Present & 9.74 & $4.27-22.23$ & $<0.001$ & - & - & NS & - & - & NS \\
\hline Coagulative necrosis & Absent & Present & 9.64 & $5.16-18.0$ & $<0.001$ & 4.22 & $2.11-8.44$ & $<0.001$ & 4.01 & $2.00-8.05$ & $<0.001$ \\
\hline Microvascular invasion & Negative & Positive & 4.30 & $2.24-8.24$ & $<0.001$ & - & - & NS & - & - & NS \\
\hline eIF4E & Low & High & 2.70 & $1.24-5.90$ & 0.013 & 4.68 & $2.07-10.61$ & $<0.001$ & & & \\
\hline p-eIF4E(S209) & Low & High & 0.48 & $0.25-0.92$ & 0.027 & 0.47 & $0.24-0.92$ & 0.029 & & & \\
\hline \multirow{2}{*}{$\begin{array}{l}\text { Phosphorylation levels } \\
\text { of eIF4E\# }\end{array}$} & Нypo & Int & 0.41 & $0.22-0.76$ & 0.005 & & & & 0.38 & $0.20-0.75$ & 0.005 \\
\hline & Нypo & Hyper & 0.07 & $0.01-0.55$ & 0.011 & & & & 0.06 & $0.01-0.46$ & 0.007 \\
\hline \multicolumn{12}{|l|}{ Cancer-specific survival } \\
\hline Pathological T stage & $\mathrm{pTa}$ & $\mathrm{pT} 1 \mathrm{~b} \leq$ & 28.49 & $3.82-212.70$ & 0.001 & 9.91 & $1.21-81.28$ & 0.033 & 9.81 & $1.19-80.61$ & 0.034 \\
\hline Pathological N stage & $\mathrm{pN} 0 / \mathrm{X}$ & $\mathrm{pN} 1$ & 10.92 & $2.51-47.51$ & 0.001 & - & - & NS & - & - & NS \\
\hline Fuhrman grade & $\mathrm{G} 1 / 2$ & $\mathrm{G} 3 / 4$ & 12.37 & $4.79-31.96$ & $<0.001$ & 4.27 & $1.53-11.93$ & 0.006 & 3.88 & $1.37-10.99$ & 0.011 \\
\hline $\begin{array}{l}\text { Sarcomatoid } \\
\text { differentiation }\end{array}$ & Absent & Present & 6.28 & $1.82-21.72$ & 0.004 & - & - & NS & - & - & NS \\
\hline Coagulative necrosis & Absent & Present & 12.53 & $5.17-30.33$ & $<0.001$ & 4.17 & $1.56-11.16$ & 0.005 & 4.21 & $1.55-11.43$ & 0.005 \\
\hline Microvascular invasion & Negative & Positive & 4.15 & $1.71-10.05$ & 0.002 & - & - & NS & - & - & NS \\
\hline eIF4E & Low & High & 3.40 & $1.11-10.36$ & 0.032 & 3.66 & $1.21-11.04$ & 0.021 & & & \\
\hline p-eIF4E(S209) & Low & High & 0.46 & $0.18-1.14$ & 0.092 & - & - & NS & & & \\
\hline \multirow{2}{*}{$\begin{array}{l}\text { Phosphorylation levels } \\
\text { of eIF4E\# }\end{array}$} & Нypo & Int & - & - & NS & & & & - & - & NS \\
\hline & Нуро & Hyper & - & - & NS & & & & - & - & NS \\
\hline
\end{tabular}

Abbreviations: ccRCC; clear cell renal cell carcinoma, CI; confidential interval, HR; hazard ratio, ref.; reference, eIF4E; eukaryonic translation initiation factor 4E, p-eIF4E; phospho-eIF4E, NS: not significant. Hypo; hypophosphorylation, Int; intermediate phosphorylation, Hyper; hyperphosphorylation, \#; Combinations of high eIF4E with low p-eIF4E, low eIF4E with high p-eIF4E or high eIF4E with low p-eIF4E, and low eIF4E with high p-eIF4E were defined as hypo-, intermediate, and hyper-phosphorylation levels of eIF4E, respectively.

and CSS after curative surgery $(p=0.001$ and 0.018 , log-rank test, respectively; Supplementary Figure 4). The stratification is considered to reflect differences in the phosphorylation levels of eIF4E (Figure 1F, 1G, and Supplementary Figure 4). RFI and CSS were significantly longer as eIF4E became more phosphorylated $(p=0.001$ and $p=0.018$ in log-rank test, $p<0.001$ and $p=0.002$ in log-rank trend test, respectively; Figure 1F, 1G, and Supplementary Figure 4). Univariate and multivariate (model 2) Cox analyses revealed that the phosphorylation levels of eIF4E would be an independent predictor of recurrence-free status, but not of CSS (Table 2).

\section{Protein and mRNA expression of eIF4E, p-eIF4E, and MNKs in cell lines}

To the best of our knowledge, MNK1/2 are only physiological kinases to phosphorylate eIF4E in vivo, and the phosphorylated site is at Ser209 of eIF4E [9]. The expression levels of MNKs, eIF4E, and p-eIF4E (Ser209) were examined using fresh frozen tissue samples of ccRCC and normal kidney parenchyma from patients ( $n=28$ and 7, respectively). Cell lines were cultured, including a normal kidney cell line (human renal cortical epithelial cells: HRCEpC) and six human RCC cell lines (Figure 2C).

On the immunoblot, MNK1/2 was more expressed in ccRCC tissues than in normal kidney parenchyma, while the variable expression of eIF4E and p-eIF4E proteins was observed in ccRCC and the normal kidney (Figure 2A). At the mRNA level, MNK2, especially MNK2a, was a predominant isoform of the MNKs in ccRCC and normal kidney tissues (Figure 2B). No differences in transcript levels of MNK1, 2, 2a and 2b were found between the four categories stratified with eIF4E + p-eIF4E immunohistochemical (IHC) expression 
A

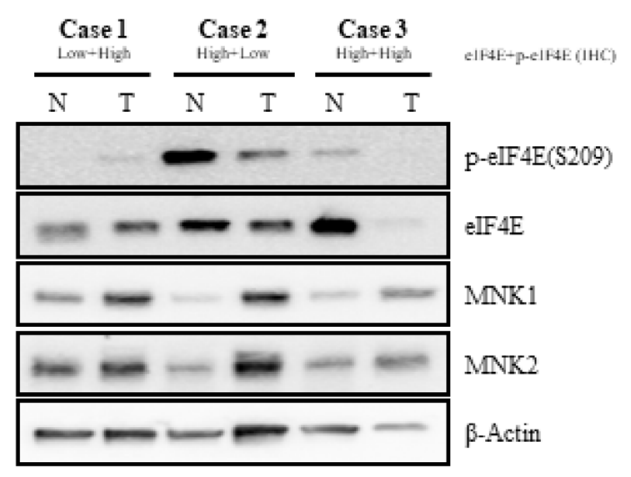

B

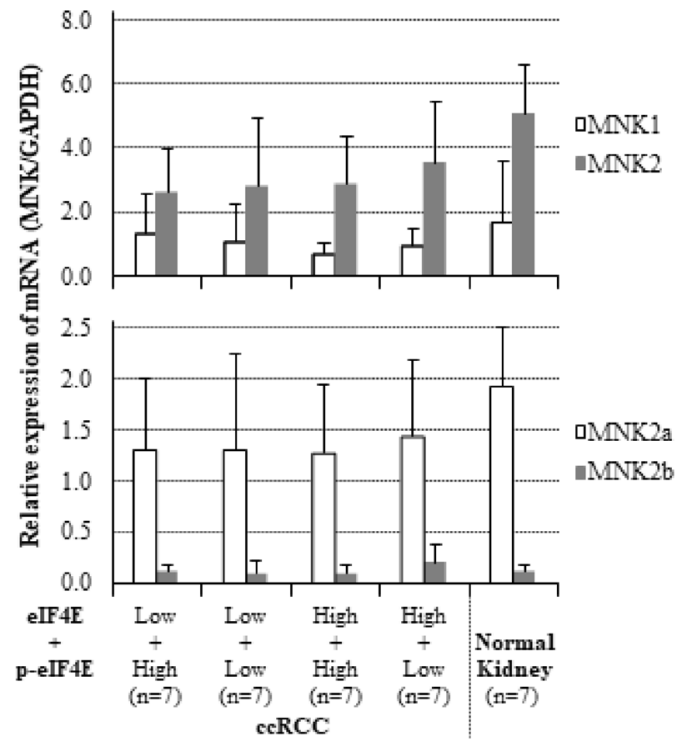

C

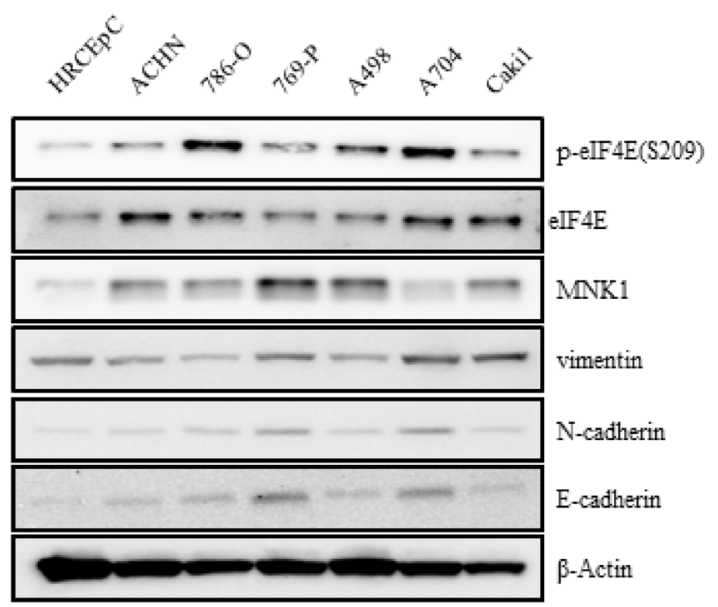

D

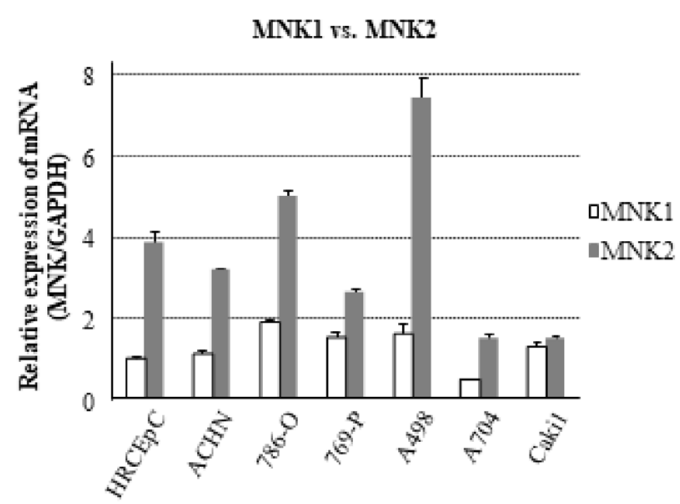

$\mathbf{E}$

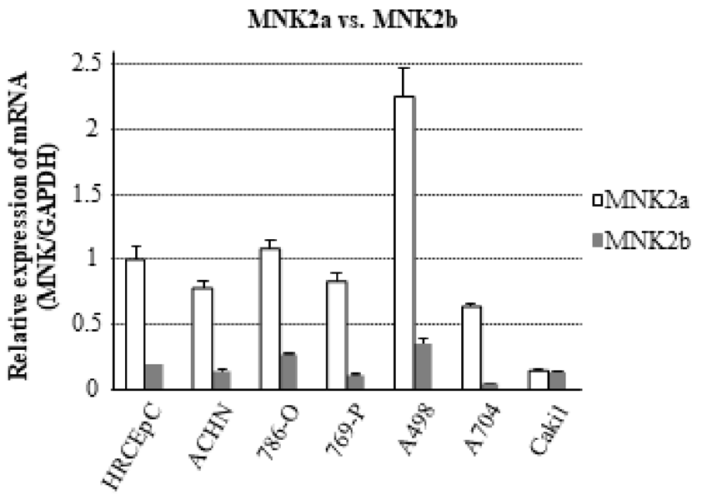

Figure 2: Expressional differences in MNK/eIF4E signaling and molecular markers on EMT. (A) Protein expression of eIF4E, p-eIF4E, MNK1, and MNK2 in ccRCC and the normal kidney on an immunoblot. Cases 1, 2, and 3 belonged to different groups stratified with a combination of eIF4E with p-eIF4E IHC stainability in Figure 1F and 1G. (B) Relative transcript levels of MNKs in ccRCC and the normal kidney tissues. (C) Protein expression of eIF4E, p-eIF4E, MNK1, and EMT markers in cell lines on an immunoblot. (D) Relative levels of MNK1 and MNK2 mRNAs in HRCEpC and RCC cell lines. (E) mRNA levels of MNK2a and MNK2b in HRCEpC and $\mathrm{RCC}$ cell lines. The experiments were repeated at least three times. Representative data are shown. Error bars show standard deviations. Abbreviations. N: the normal kidney parenchyma, T: tumour, HRCEpC: human renal cortical epithelial cell. 
in ccRCC. Compared with HRCEpC, MNK1, eIF4E, and p-eIF4E proteins were more expressed in the RCC cell lines (Figure 2C). Expression profiles of MNK1 at mRNA and protein levels were similar among the cell lines except for A704, whereas MNK2 mRNA levels were greatly different among cell lines (Figure 2D and 2E). Variabilities of protein levels of MNK1:p-eIF4E expression were observed on the immunoblot, implicating the potential involvement of MNK2-dependent eIF4E phosphorylation (Figure 2C). Herein, in experiments with cell lines, we were unable to investigate MNK2, 2a, or $2 \mathrm{~b}$ protein expression by western blotting due to the commercial unavailability of specific antibodies that are reliable for detecting MNK2s [10]. Instead, MNK mRNAs levels were quantified by reverse transcriptionpolymerase chain reaction (RTPCR) (Figure $2 \mathrm{D}$ and $2 \mathrm{E}$ ). At transcript level, MNK2, especially MNK2a, was a predominant isoform of the kinases in HRCEpC and RCC cell lines. In Caki1, MNK2 and 2a mRNAs were expressed in amounts comparable to or more than those of MNK1 and 2b.

Taken together, eIF4E would be phosphorylated mainly by MNK2 (MNK2a) in ccRCC and the normal kidney parenchyma. In the following experiments, 786-O and A498 cell lines were used as typical ccRCC models with poorly and moderately differentiated features, respectively $[11,12]$.

\section{Effects of MNK inhibition on p-eIF4E and epithelial-mesenchymal transition (EMT) markers in 786-O and A498 cells}

We examined the influence of MNK inhibition on eIF4E phosphorylation in 786-O and A498 using a smallmolecule MNK1/2 inhibitor CGP57380 (a classical agent) [9] or ETP45835 (recently developed) [13] (Figure 3A). In 786-O cells, CGP57380 and ETP45835 prevented eIF4E phosphorylation in a concentration-dependent manner and at the same time increased vimentin and N-cadherin levels (Figure 3A, left). Similarly, in A498 cells, p-eIF4E (vs. total eIF4E expression) was reduced in a concentrationdependent manner after CGP57380 or ETP45835 administration, with the reciprocal upregulation of vimentin and $\mathrm{N}$-cadherin in parallel. E-cadherin appeared stable on the immunoblot, but this was hard to determine definitely because the bands of E-cadherin were too weak (Figure 3A, right).

Next, we attained sufficient knockdown of MNKs in 786-O and A498 using newly designed small interfering (si)-RNAs specific to MNK1, 2, or 2a mRNAs (Figure 3B). Under these conditions, MNK2 and 2a knockdown caused p-eIF4E reduction, although MNK1 knockdown had little effect on p-eIF4E expression (Figure 3C). In parallel, E-cadherin faintly decreased and vimentin became overexpressed at the protein level in 786-O and A498 cells with MNK2 or 2a knockdown (Figure 3C). Compared with RCC cells laden with a negative control (NC) of siRNA, however, no significant increase in vimentin mRNA was observed in the MNKs-knockdown cells, indicating that MNK knockdown may enhance translation of vimentin mRNA, but not its transcription (Figure 3D).

These findings suggest that MNK2a, but not MNK1, may phosphorylate eIF4E. They also suggest that MNK2a may suppress EMT in 786-O and A498 cells partially through negative regulation of vimentin at the translation level. However, the effects of siMNK2a on p-eIF4E were less than those of siMNK2 in A498 cells, implicating that MNK2b may be somewhat involved in phosphorylation of eIF4E depending on the cell type.

\section{Effects of MNK inhibition on cell migration, invasion and proliferation in $786-\mathrm{O}$ and $\mathrm{A} 498$}

Figure 4A-4C shows the results of the scratch wound-healing assay for investigating the cell migration in MNKs-knockdown RCC cells. In 786-O and A498 cell lines, siMNK2 and siMNK2a significantly increased cell migration, compared with NC-siRNA. siMNK1 induced a remarkable increase in 786-O migration to the same extent as siMNK2 and siMNK2a. However, the enhancement by siMNK1 was not observed in A498. The Matrigel invasion assay demonstrated that siMNK2 and siMNK2a significantly enhanced cell invasion in 786$\mathrm{O}$ and A498 (Figure 4D and 4F). In 786-O (but not in A498), knockdown with siMNK1 increased cell invasion approximately by twofold vs. the NC, comparable with that of siMNK2 or siMNK2a (Figure 4E and 4F).

The pharmacological inhibition of MNK1/2 with CGP57380 suppressed cell viability in a concentrationdependent manner, but the maximal effects at $100 \mu \mathrm{M}$ CGP57380 were approximately a $30 \%$ and $10 \%$ decrease from the baselines in 7860 and A498, respectively (Figure 4G). However, CGP57380 inhibits several kinases other than MNKs [14]. Another MNK1/2 inhibitor, ETP45835, had no effect on cell viability of 786-O and A498 at a concentration of 1 to $100 \mu \mathrm{M}$ (Figure 4G). In 786-O cells treated with specific siRNAs against MNK1, 2, or 2a, cell viability was not altered at all (Figure $4 \mathrm{H})$. In contrast, cell viability decreased by $30 \%$ in A498 cells with MNK2 or 2a knocked down, but not in those with MNK1 knocked down (Figure 4I).

$\mathrm{MNK} 1 / 2$ is related largely to cell migration and invasion rather than proliferation. MNK2a acts as a suppressor of cell migration and invasion, while MNK1 may be variably involved with migration and invasion, dependent on individual RCC cell lines.

\section{DISCUSSION}

eIF4E expression and/or activity are increased in numerous cancers, playing a prooncogenic role $[5,6,9,10]$. Consistent with a previous report [15], our results show that high eIF4E expression is independently 
A

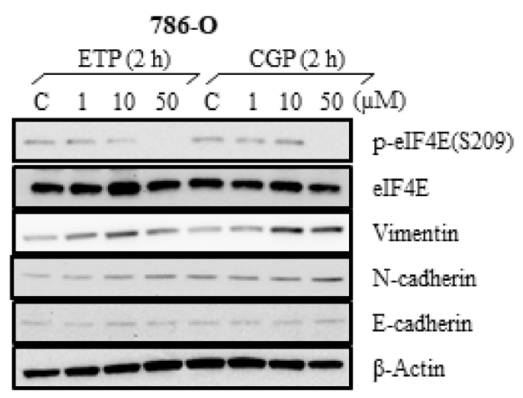

B

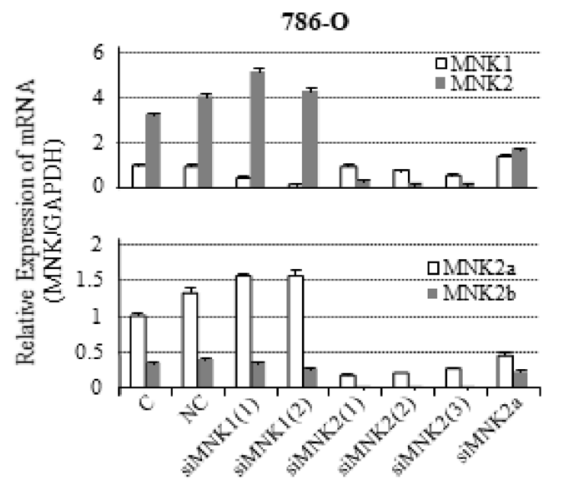

C

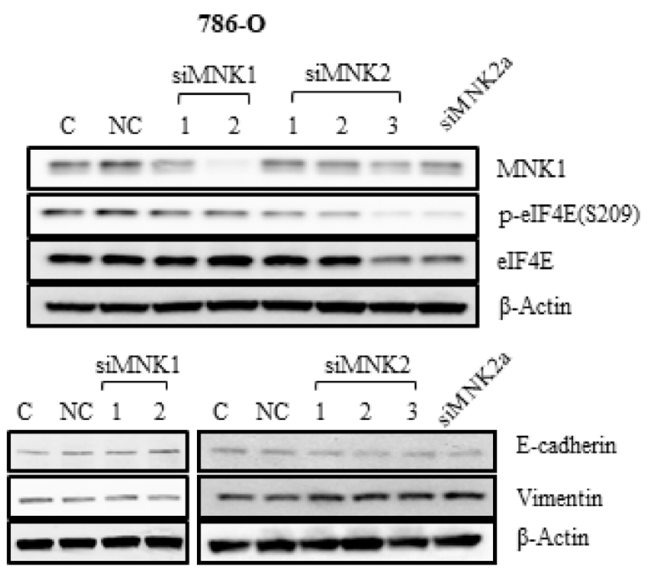

D

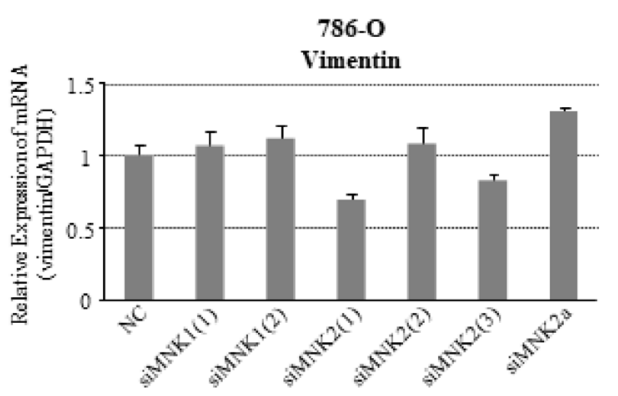

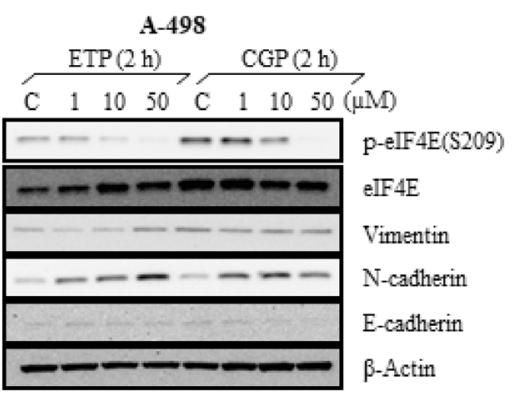
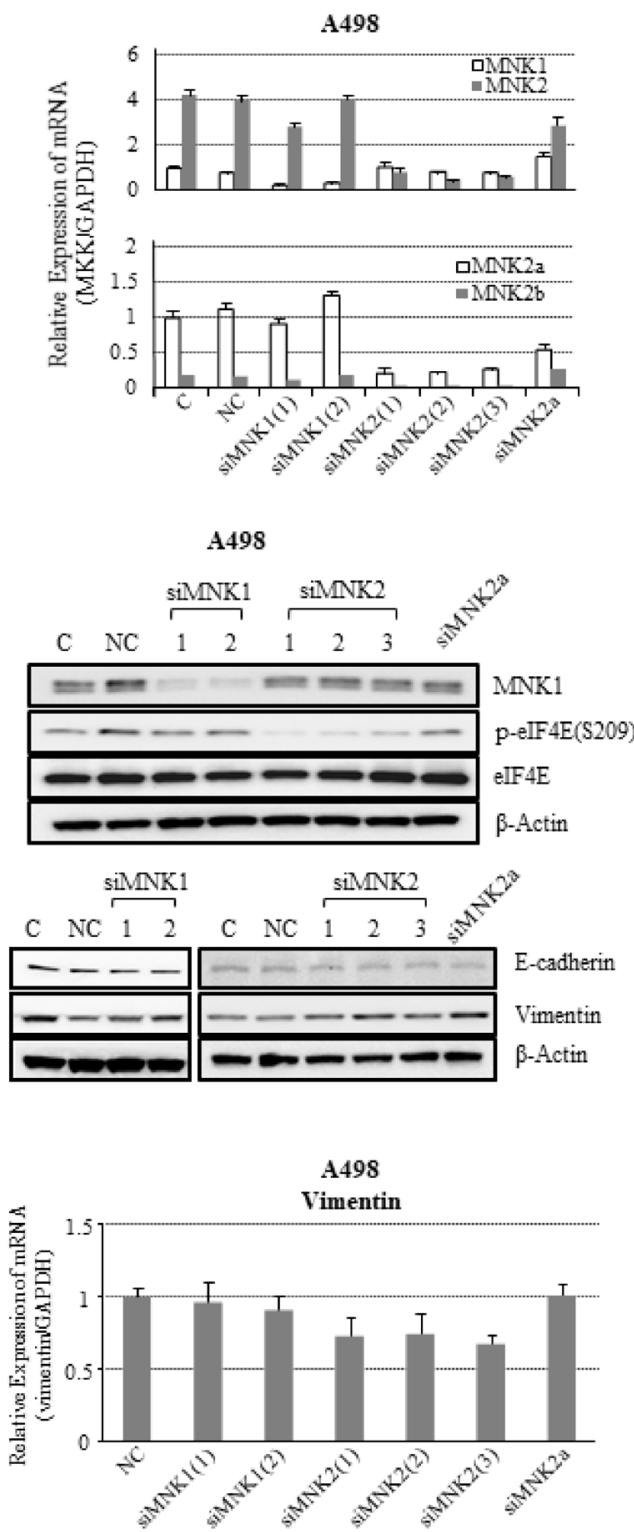

Figure 3: Effects of MNK inhibition on MNK/eIF4E signaling and expression of EMT markers in 786-O and A498 cells. (A) MNK1/2 were pharmacologically inhibited with a small-molecule agent, either CGP57380 or ETP45835 at concentrations of 0-50 $\mu \mathrm{M}$ for $2 \mathrm{~h}$. (B) siRNAs specific to MNK1, MNK2, or MNK2a mRNAs successfully knocked down MNKs in 786-O and A498. Herein, the controls indicate conditions without any siRNA transfection. Each bar represents relative amounts of mRNA vs. MNK1 and MNK2a mRNA set as references, respectively. Error bars show standard deviations. (C) MNK2 and MNK2a knockdown lowered p-eIF4E expression, but MNK1 knockdown did not affect it significantly. Increase in vimentin and decrease in E-cadherin at protein levels in parallel with MNK2 or MNK2a knockdown, reflecting enhancement of EMT. (D) No significant increase in vimentin mRNA after knockdown of MNKs. Representative results are presented. The experiments were repeated at least three times. Abbreviations. C: control, NC: negative control. 
A

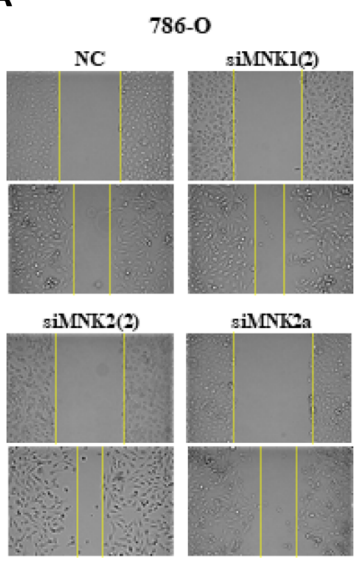

D

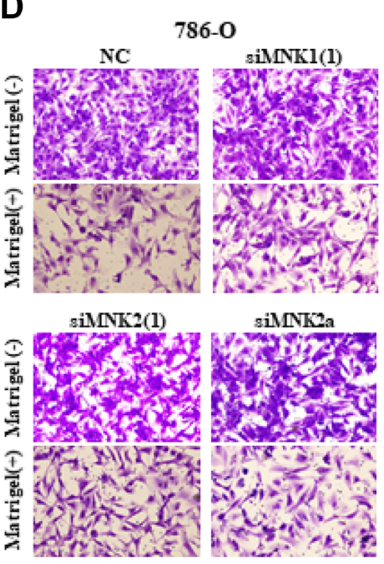

G

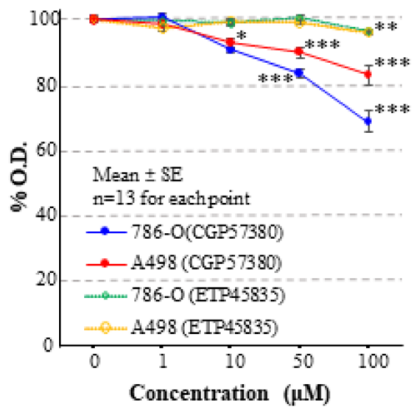

B

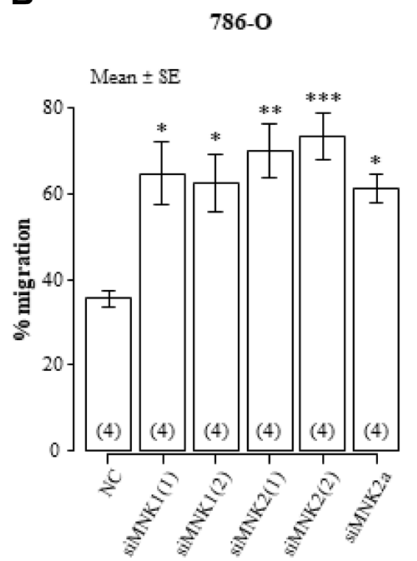

E

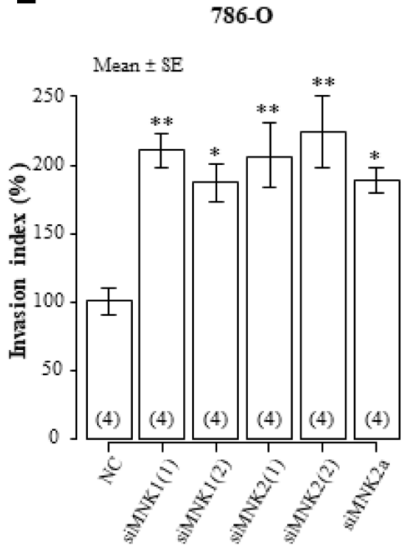

H

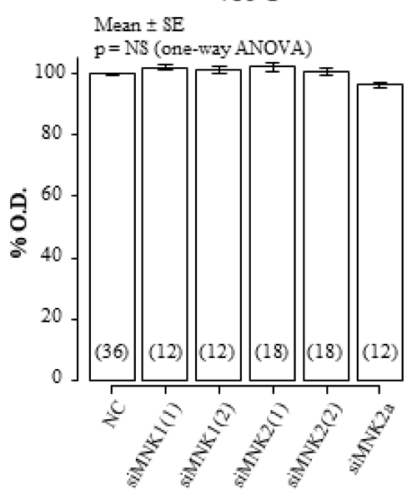

C

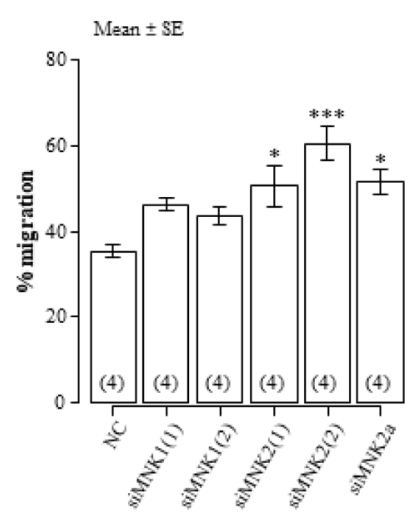

F
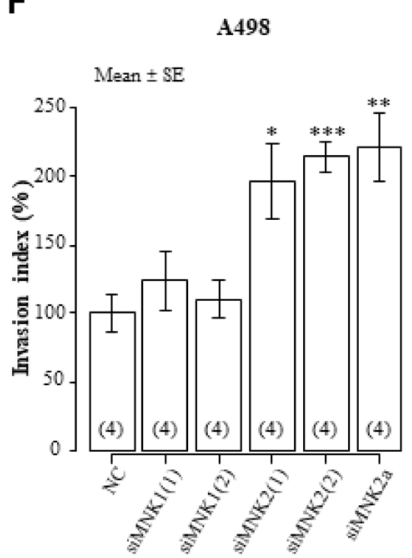

I

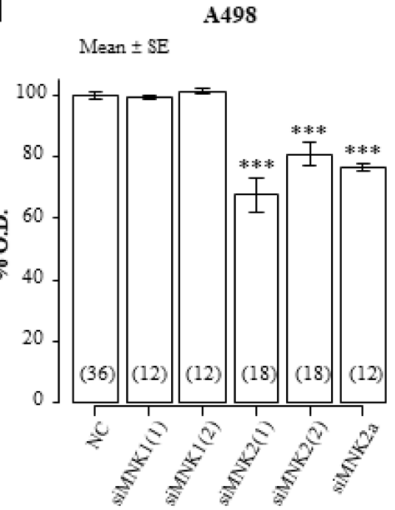

Figure 4: Effects of MNK inhibition on cell migration, invasion, and proliferation of 786-O and A498. (A-C) Scratch wound-healing assay under siRNA-treated conditions. (A) Representative actual images of 786-O migration for $7 \mathrm{~h}$. Pooled data on the \% migration of 786-O (B) and A498 cells (C) are presented as bar plots ( $p<0.001$ for each; one-way ANOVA). The data number is indicated in parenthesis at the bottom of each bar from four independent experiments. (D-F) Transwell invasion assay under siRNA-treated conditions. (D) Representative actual images of 786-O invasion through an $8 \mu \mathrm{m}$-sized porous membrane at $24 \mathrm{~h}$ in the absence and presence of Matrigel. Pooled data on the invasion index of 786-O (E) and A498 cells (F) are presented as bar plots $(p=0.001$ and $<0.001$, respectively; one-way ANOVA). The data number is indicated in parenthesis at the bottom of each bar from four independent experiments (G-I). Cell viability was evaluated using an MTS assay under the conditions that MNKs were inhibited pharmacologically $(\mathrm{G})$ or genetically with siRNAs ( $\mathrm{H}$ and I) in 786-O and A498. The data number is indicated in parenthesis at the bottom of each bar from 6 independent experiments. Statistical significance was determined by one-way ANOVA followed by post-hoc test with Bonferroni adjustment; "indicates $p<0.05$; **indicates $<0.01$; ***indicates $<0.001$ in multiple comparison tests with Bonferroni adjustment. Representative results are presented. Error bars show standard errors. Abbreviations. NC: negative control. 
prognostic of poor recurrence-free rate and CSS in the patients with localized ccRCC. However, the oncological relevance of peIF4E in $\mathrm{RCC}$ remains unclear. In the present study, we have demonstrated that higher expression of p-eIF4E is an independent predictor of longer RFI after curative nephrectomy for localized ccRCC. Cell migration and invasion are broadly regulated by EMT and are important processes in cancer metastasis [16]. The present data suggest that MNK2a-induced p-eIF4E may suppress EMT, cell migration, and invasion, partially due to vimentin downregulation at the translational level, consequently inhibiting ccRCC recurrence.

Significant correlations between p-eIF4E expression and poor prognosis have been reported on various tumours [17-21]. However, in the present study, p-eIF4E may associate with the negative regulation of eIF4E activity, as indicated in some other tumours including ovarian, gastric, and colorectal cancers $[22,23]$. MNK1/2 kinases are more expressed in RCC than in the normal kidney tissue and HRCEpC. MNK2a, a predominant isoform of the MNKs in RCC, may work as a central player in eIF4E phosphorylation to regulate EMT and metastasis negatively in localized ccRCC. These findings strongly favour the clinical relation between higher (or lower) peIF4E expression and longer (or shorter) RFS of patients with localized ccRCC, respectively.

MNK2a can be negatively controlled through its phosphorylation at Ser437 by mTORC1 [24]. Conversely, MNK2 selectively interacts with mTORC1 in a kinaseindependent manner and inhibits S6K phosphorylation [25]. Recently, we demonstrated that the lower or higher expression of eIF4E reflected a weaker or stronger activation of the mTORC1/4EBP1/eIF4E signalling pathway, respectively [26]. In the present study, significantly lower eIF4E and higher p-eIF4E expressions were observed in ccRCC patients who did not experience tumour recurrence than in those who did. In the patients with better prognosis, hypofunction of mTORC1 may suppress mTORC1/4EBP1/eIF4E signalling to reduce eIF4E release from 4EBP1 [5, 9], and simultaneously may stimulate MNK2a to boost up eIF4E phosphorylation [24].

The molecular hallmarks of EMT are canonically the decrease in epithelial traits, including E-cadherin and

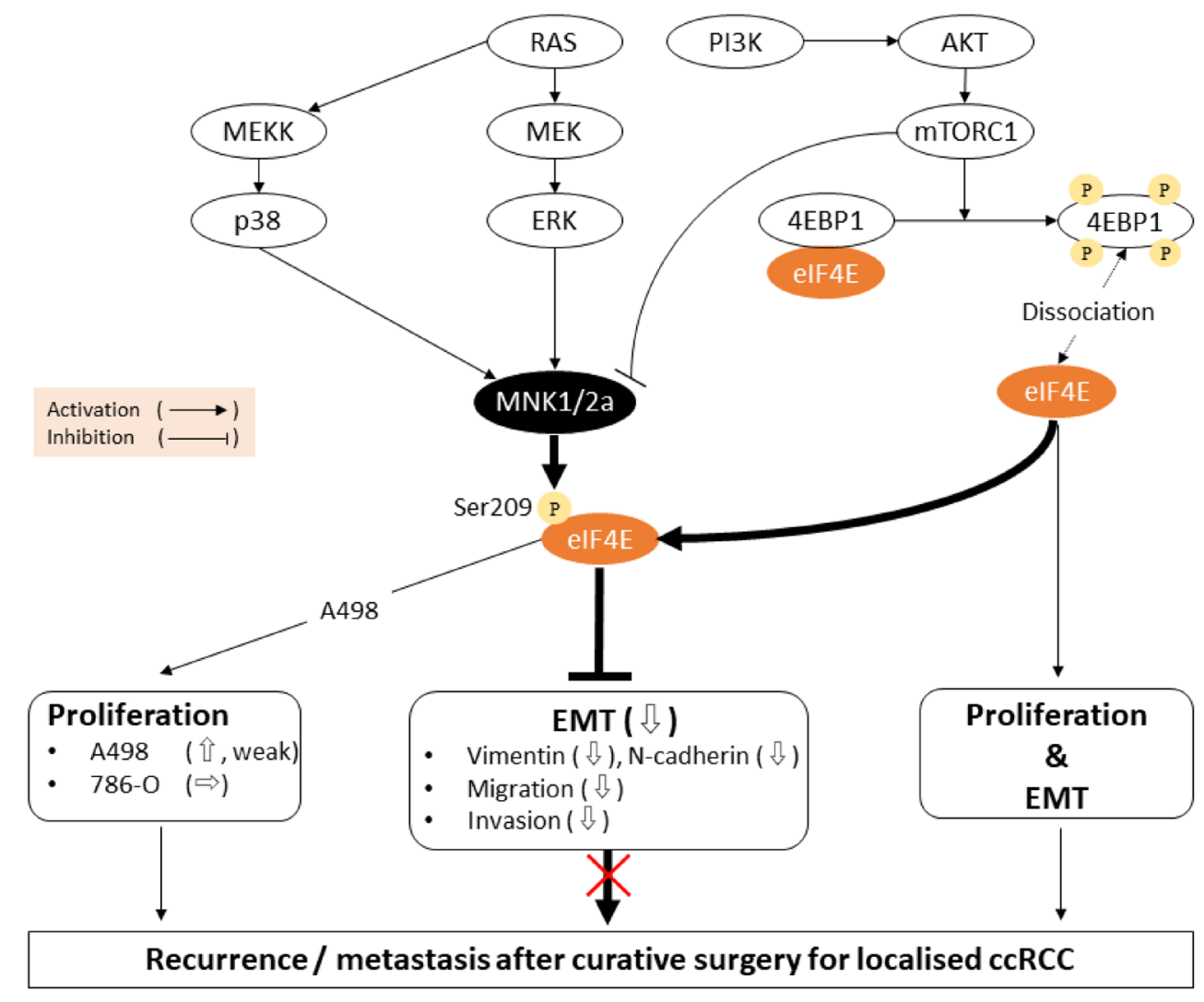

Figure 5: Schematic diagrams of the signaling pathways and biological reactions in this study. The MNK/eIF4E axis is located at the downstream of two major intracellular signalling, mTORC1/4EBP1/eIF4E and Ras/MEK/extracellular signal-regulated kinase pathways (ERK). MNK2a may predominantly phosphorylate eIF4E due to the higher expression than MNK1 and MNK2b in ccRCC. MNK2a-induced p-eIF4E inhibits the biosynthesis of EMT-related proteins (e.g., vimentin), and suppresses cell migration and invasion, leading to the decrease in metastatic recurrence of ccRCC after curative nephrectomy. MNK2a is weakly involved in cell proliferation in A498 cells. The mechanism that MNK1 inhibits 786-O migration and invasion has been unresolved. Downward, upward, and horizontal open arrows represent a decrease, an increase, and no change, respectively. 
the increase in mesenchymal features such as vimentin and $\mathrm{N}$-cadherin, leading to facilitated motility, plasticity, and stemness of tumour cells $[16,27]$. Vimentin expression could predict poor clinical outcomes of RCC [28, 29], independently of grade and stage $[30,31]$. In the present study, MNK2 or $2 \mathrm{a}$ inhibition augmented migration, invasion and vimentin expression to promote EMT. In contrast, in pancreatic, breast and lingual cancer cells, MNK inhibition reduces vimentin protein levels and reverses EMT $[32,33]$. Maimon et al. demonstrated that MNK2a and $2 \mathrm{~b}$ play anti- and prooncogenic roles with an opposing function, respectively, suggesting that a balanced level of their antagonism could determine a whole nature of a tumour [34]. In triple-negative breast cancer cells that predominantly express MNK1, MNK1b overexpression with gene transfection facilitates cell migration and invasion [35]. The overwhelming antagonism of abundant MNK2a against MNK2b in ccRCC may suppress EMT along with p-eIF4E upregulation (Figure 5). To our speculation, the antagonistic balance between MNKa and $\mathrm{b}$ in a major MNK1/2 isoform could possibly control EMT progressively or reversely.

Relationships among MNK activity, p-eIF4E and proliferation have not been fully resolved [10]. Neither MNK activity nor p-eIF4E was required for normal cell proliferation $[36,37]$. In breast cancer cells overexpressing MNK1a or $1 \mathrm{~b}$ with gene transfection, cell viability was increased or remained stable depending on the cell lines [35]. Colony formation was greatly impaired in mesenchymal embryonic fibroblasts expressing eIF4E with mutation of Ser209 to alanine which MNKs cannot phosphorylate, but the fibroblasts proliferated comparably as those with wildtype eIF4E [21]. Our results show that MNK2/2a inhibition supressed cell proliferation by 20 $25 \%$ in A498 cells but did not in $786-O$ cells. These data support the remark that the MNK/eIF4E axis is not tightly connected to tumour proliferation and growth [10].

Our study has some limitations. Firstly, this study was retrospective at a single centre, without consideration of prognostic factors, such as hypertension, obesity and smoking habits [38]. Secondly, molecular subtyping of ccRCC was not performed [39, 40]. Thirdly, ccRCC heterogeneity in gene expression and intracellular signalling was not considered [41]. In the present study, eIF4E and p-eIF4E expression on immunoblot was partially inconsistent with IHC classification of eIF4E phosphorylation levels. The discrepancy may result from the heterogeneity within a tumour. Fourthly, it was not possible to investigate the effects of specific MNK inhibition on p-eIF4E in mouse xenograft models, because stable MNK knockdown in RCC cell lines with short hairpin RNA significantly decreased eIF4E protein expression under our experimental conditions. Further studies are needed to confirm the present findings.

In conclusion, lower eIF4E and higher p-eIF4E expression is an independent predictor of longer RFI after curative nephrectomy for localized ccRCC. MNK2a may predominantly phosphorylate eIF4E due to the higher expression than MNK1 and MNK2b in ccRCC. MNK2a-induced phosphorylation of eIF4E inhibits the biosynthesis of EMT-related proteins and ultimately suppresses metastatic recurrence of ccRCC. The present data suggest that the activity of MNK2a/eIF4E axis may provide a rationale for stratifying ccRCC patients at risk of recurrence and a therapeutic strategy for ccRCC.

\section{MATERIALS AND METHODS}

\section{Reagents and antibodies}

MNK inhibitors, CGP57380 (cat. No; 13322) and ETP45835 (cat. No; 5183) were purchased from Cayman Chemical (Ann Arbor, MI, USA) and Tocris Bioscience (Bristol, UK), respectively. For immunoblot and immunohistochemistry (IHC), the antibodies to eIF4E (cat. No; 2067) and MNK1 (cat. No; 2195) were bought from Cell Signaling Technology Japan (Osaka, Japan). Antibodies to vimentin (cat. No; 550513), N-cadherin (cat. No; 610920), and E-cadherin (cat. No; 610181) were bought from BD Bioscience (Franklin Lakes, NJ, USA). Anti- $\beta$-actin (cat. No; ab49900) and p-eIF4E (Ser209) (cat. No; ab76256) antibodies were obtained from Abcam Inc. (Cambridge, MA, USA). An antibody to MNK2 (cat. No; 17354-1-AP) was purchased from Proteintech Japan (Tokyo, Japan).

\section{Collection and acquisition of patients' clinical data and tumour specimens}

We retrospectively explored medical archives of consecutive patients who underwent curative surgery for localized ccRCC in Yamagata University Hospital from 1997 to 2011. Patients with genetic disorders predisposing ccRCC (such as VHL disease, distant metastasis, synchronous bilateral RCC), or those undergoing neoadjuvant or adjuvant anti-tumour chemotherapy with molecular-targeted drugs, or those with preoperative arterial embolisation were excluded from the present study. For inclusion criteria, patients were pathologically diagnosed with ccRCC, and the surgical specimens were available as formalin-fixed paraffin-embedded blocks. Finally, 290 patients with localized ccRCC were eligible for the present study. Clinical and pathological information on the patients were collected from medical records.

\section{Pathology, immunohistochemistry and semi- quantitative evaluation}

\section{Pathologic examination}

All specimens surgically obtained were fixed in $10 \%$ buffered formalin and embedded in paraffin blocks, 
and were diagnosed by staff pathologists according to the routine procedures in the institution. T classification and pathological findings were re-assessed for the present study, according to the World Health Organization classification 2004 [42], and the 2010 American Joint Committee on cancer TNM staging system (T.K., M.Y.) [43]. A single representative block was selected for each patient.

\section{Immunohistochemistry}

The IHC staining against eIF4E and p-eIF4E (Ser209) was carried out with a standard procedure described elsewhere [26]. The detailed procedures were provided as part of Supplementary Materials and Methods.

\section{Semi-quantitative evaluation and grading of eIF4E phosphorylation levels}

Immunohistochemically stained sections were evaluated with a semi-quantitative method as described elsewhere [26]. The expression of the proteins detected by IHC was scored with the mean area and staining intensity of positive tumour cells on an Olympus BX50 microscope (Olympus Corporation, Tokyo, Japan). Brown-coloured staining of tumour cells, regardless of the cytoplasmic or nuclear stainability, was judged as positive for antieIF4E and p-eIF4E antibodies. The mean area of staining cells was evaluated as staining area $\leq 50($ score $=-)$ or $>50 \%($ score $=1+)$ of tumour cells. The mean staining intensity was graded as negative ( $($ score $=1+)$, and strong $($ score $=2+)($ Figure $1 \mathrm{~A})$. The semi-quantitative evaluation of IHC slides was made by two observers (O.I, and S.N.) independently without the knowledge of the clinical outcomes of the corresponding patients. If there was any discrepancy between the observers, they re-analysed the slides together and made a consensus of the final evaluation. The final scores were obtained through the addition of area and intensity scores. High expression was defined as a strong positive intensity with $>50 \%$ staining area (final scores $=3+$ ), and patients with final scores $\leq 2+$ were defined as having low protein expression. Phosphorylation levels of eIF4E was graded as hypo, intermediate, and hyper -phosphorylation, based on a combination of eIF4E and p-eIF4E expression: Combinations of high eIF4E with low p-eIF4E, and low eIF4E with high p-eIF4E indicated hypo and hyperphosphorylation levels of eIF4E, respectively. Low eIF4E plus low p-eIF4E or high eIF4E plus high p-eIF4E were categorised as the intermediate phosphorylation level.

\section{Preparation of ccRCC and normal human kidney tissues}

Fresh frozen tissue samples obtained from patients with RCC ( $n=28)$ who underwent nephrectomy at
Yamagata University Hospital were used in the present study. Each of the tumour specimens came from a sample per patient. Non-tumourous renal parenchymal specimens away from RCC areas $(n=7)$ were obtained from different 7 patients of the 28 cases. Samples cut from ccRCC tissues as well as samples of non-tumorous kidney parenchyma were freshly frozen and maintained at $-80^{\circ} \mathrm{C}$ during storage.

\section{Cell culture}

The RCC cell lines ACHN, 786-O, 769-P, A498, A704, and Caki1 were obtained from the American Type Culture Collection (Manassas, VA, USA). Cells were cultured in RPMI medium supplemented with $50 \mu \mathrm{g} /$ $\mathrm{mL}$ of kanamycin and $10 \%$ foetal bovine serum in an incubator at $5 \% \mathrm{CO}_{2}$ and $37^{\circ} \mathrm{C}$. HRCEpC was obtained from PromoCell GmbH (Heidelberg, Germany). Cells were cultured in Renal Epithelial Cell Growth Medium 2 (PromoCell $\mathrm{GmbH}$ ) including growth supplements in an incubator at $5 \% \mathrm{CO}_{2}$ and $37^{\circ} \mathrm{C}$. In most experiments, 786-O (mutated in VHL and PTEN) and A498 (mutated in SETD2 and often $V H L$, and high HIF $2 \alpha$-laden) cell lines were used as ccRCC models with poorly and moderately differentiated features, respectively $[11,12]$.

\section{Immunoblot analysis}

The immunoblot analysis was performed as described previously [44], using SuperSignal West Pico Substrate (Pierce, Rockford, IL, USA) and Western BLoT Hyper HRP Substrate (Takara Bio Inc., Shiga, Japan) according to the manufacturers' instructions. Images were analysed using UN-SCAN-Itgel Automated Digitizing System software (Version 5.1 for Windows, Silk Scientific Inc., Orem, UT, USA). The antibodies to the following chemicals were used: eIF4E, p-eIF4E (Ser209), MNK1, MNK2, vimentin, N-cadherin, and E-cadherin. $\beta$-actin was used as a loading control.

\section{Quantitative RT-PCR (qRT-PCR)}

The general procedures for qRT-PCR were provided as part of Supplementary Materials and Methods. MNK1, 2, and 2a mRNAs were quantified using qRTPCR and their amounts were compared among RCC cell lines. Sequences of the primers used are shown in Supplementary Figure 1.

\section{SiRNA transfection}

For MNKs silencing, 786-O and A498 cells were transfected with specific human siRNAs against MNK1 ( 1 or $10 \mathrm{nM}$ ), MNK2 (5 or $10 \mathrm{nM}$ ), or MNK2a (5 or 10 $\mathrm{nM}$ ) by using Lipofectamine RNAiMAX (Invitrogen, Thermo Fisher Scientific Inc.) according to the 
manufacture's recommendations. Targeting sequences of MNKs siRNA are as follows: siMNK11 (\#161707029), 5'-GCCGUCAAAAUCAUCGAGAAACAAG-3'; siMNK12 (\#161707032), 5'-GUUUACAGAUGGUA UCUUCUCAAAA-3'; siMNK21 (\#158253115), 5'-GA AGUUUUCCUUUACACCAACUGTC-3'; siMNK22 (\#158253118), 5'-GCCUUGGACUUUCUGCAUAAC AAAG-3'; siMNK22 (\#165395347), 5'-AGUGCAGAC CUGCAUCAACCUCATC-3'; siMNK2a (\#165395350), 5'-CUUGUCCCCAUGAUAGUUGACAATC-3' (all from Integrated DNA Technologies, Inc. Tokyo, Japan). Nonspecific control siRNA (Integrated DNA Technologies, Inc.) was used as NC.

\section{Scratch wound-healing assays}

Six-well culture dishes containing a single layer of either 786-O or A498 cells were treated with siRNA transfection then immersed in $2 \mathrm{ml}$ growth medium.

Afterwards, they were scratched using a pipette tip to form a wound across the diameter. After being washed twice with phosphate buffered saline to remove any debris, cells were incubated in the media at $37^{\circ} \mathrm{C}$ for $7 \mathrm{~h}$, and could migrate into the wound for the period of time. At 0h and 7h, a BZ-X700 microscope (Keyence Co. Osaka, Japan) was used to take images ( $\times 10$ objective lens). Wound healing was assessed by tracing the borders of the wound. The average percentage of cell-free area after cell culture compared to the initial area was calculated using the Image J software (version 1.50, https://imagej.nih.gov/ij/index.html).

\section{Cell invasion assay}

A cell invasion assay was performed according to manufacturer's instructions (https://www.corning.com). Cells $\left(1.0 \times 10^{5}\right.$ per well $)$ transfected with siRNA against MNKs or NC were seeded on top of the Matrigel-coated insert with $8 \mu \mathrm{m}$ pores in serum-free RPMI medium in the upper chambers (Corning BioCoat Matrigel Invasion Chamber; \# 354480, Corning International, Tokyo, Japan). The medium supplied with $10 \%$ foetal bovine serum was used in the lower chamber. After $24 \mathrm{~h}$ incubation, the cells on top of the inserts were scraped off using a cotton swab. The cells at the bottom of the inserts were fixed and stained with crystal violet. Cell images were captured on an Olympus BX43 microscope equipped with an Olympus DP21 camera and were analysed for cell numbers with the Image J software. Invaded cells were counted under $\times 200$ magnification in at least five representative fields and the mean for each chamber was determined. The \%invasion is defined as the percentage of cells having crossed the porous membrane of the chambers in the presence of a layer of Matrigel versus in its absence. The invasion index was calculated as follows: (\%invasion in the experimental group $/ \%$ invasion in the control group) $\times 100$. The experiments were repeated at least three times.

\section{Cell proliferation assay}

786-O and A498 RCC cells were cultured at $72 \mathrm{~h}$ in the presence and absence of MNK1/2 inhibitors, CGP57380 or ETP45835. The cells transfected with siRNA against MNKs or NC were cultured at $48 \mathrm{~h}$. Cell viability was estimated as \%O.D. values using CellTiter 96 Aqueous One Solution Cell Proliferation Assay (Promega) as described previously [44].

\section{Statistical analyses}

Comparisons between two categories were performed using cross tabulation and Chisquare or Fisher's exact tests. A Kaplan-Meier survival curve analysis and a logrank test were used to estimate and compare postoperative intervals of recurrencefree states and CSS between two groups. When the overall test result was statistically significant, a log-rank trend test was performed in case of examining a tendency among three groups. The RFI was defined as the duration from the treatment initiation (curative surgery) to the first appearance of a metastasis or local emergence of tumours at, or adjacent to, the primary site. The CSS interval was defined as the duration of followup calculated from the date of surgery to the date of death or last follow-up. The variables that significantly contributed to prognosis by univariate analyses were investigated by multivariate analysis. The prognostic variables in predicting recurrence-free and CSS rates were assessed by univariate and multivariate Cox proportional hazards analysis. A stepwise regression method was carried out with a significance level of 0.05 for variable entering.

Continuous variables are presented as the median or the mean \pm standard deviation (SD) or standard error (SE). They were statistically analysed using MannWhitney's U test, $t$ test, analysis of variance (ANOVA) and, if necessary, a posthoc Bonferroni test for multiple comparisons. All pvalues were based on the twosided statistical analysis. $p<0.05$ was considered statistically significant. All analyses were performed using $\mathrm{R}$ statistical software version 3.4.1 (http://cran.rproject.org/).

\section{Ethical approval}

The present study was carried out in accordance with a protocol approved by the Ethical Committee of Yamagata University School of Medicine (No. 534 approved on March 2, 2018). The ethical boards waived the requirement for individual informed consent because the present study was retrospective, and the anonymity of the participants was ensured. This study has been performed in accordance with the ethical standards as laid down in the 1964 Declaration of Helsinki and its later amendments or comparable ethical standards. 


\section{Abbreviations}

ccRCC: clear cell renal cell carcinoma; CSS: cancer-specific survival; 4EBP1: eIF4Ebinding protein 1; eIF4E: eukaryotic initiation factor 4E; EMT: epithelialmesenchymal transition; HIF: hypoxiainducible factor; HRCEpC: human renal cortical epithelial cells; MNK: MAP kinase interacting kinase; mTORC1: mammalian target of rapamycin complex 1; MVI: microvascular invasion; NC: negative control; OS: overall survival; RFI: recurrence-free interval; SETD2: Set domain containing 2; siRNA: small interfering siRNA; VHL: von Hippel-Lindau.

\section{Author contributions}

$\mathrm{HI}, \mathrm{SN}$, and $\mathrm{OS}$ conceptualised the project, and designed the experiments. HI, SN, OS, TK, and NT performed analysis and interpretation. TK and MY performed pathological evaluation. HI, HK, TN, MU, YK, MO, TS, HN, TK, and NT collected clinical and/or experimental data. HI, SN, and OS wrote the manuscript. All authors reviewed the manuscript and gave feedback. NT oversaw the project.

\section{ACKNOWLEDGMENTS}

We would like to thank Yamagata University Faculty of Medicine and Yamagata Prefectural Kahoku Hospital for financial support for the present study, and Editage (https://www.editage.jp/) for the English language editing.

\section{CONFLICTS OF INTEREST}

The authors declare no conflicts of interest.

\section{FUNDING}

This work was financially supported by funds from the Department of Urology, Yamagata University Faculty of Medicine and Grants-in-Aid for Scientific Research from the Japan Society for Promotion of Science (15 K10573, 16 K10993, 16 K20123, and 16 K18448).

\section{REFERENCES}

1. Kanayama HO, Fukumori $\mathrm{T}$, Fujimoto $\mathrm{H}$, Nakanishi H, Ohyama C, Suzuki K, Nishiyama H, Eto M, Miki T, Kamoi K, Kubota Y, Takahashi S, Homma Y, Naito $\mathrm{S}$. Clinicopathological characteristics and oncological outcomes in patients with renal cell carcinoma registered in 2007: The first large-scale multicenter study from the Cancer Registration Committee of the Japanese Urological Association. Int J Urol. 2015; 22:S1-7. https://doi. org/10.1111/iju.12826. [ubMed]
2. Gupta K, Miller JD, Li JZ, Russell MW, Charbonneau C. Epidemiologic and socioeconomic burden of metastatic renal cell carcinoma (mRCC): a literature review. Cancer Treat Rev. 2008; 34:193-205. https://doi.org/10.1016/j. ctrv.2007.12.001. [PubMed]

3. Calvo E, Schmidinger M, Heng DY, Grünwald V, Escudier B. Improvement in survival end points of patients with metastatic renal cell carcinoma through sequential targeted therapy. Cancer Treat Rev. 2016; 50:109-17. https://doi. org/10.1016/j.ctrv.2016.09.002. [PubMed]

4. Stewart SB, Thompson RH, Psutka SP, Cheville JC, Lohse CM, Boorjian SA, Leibovich BC. Evaluation of the National Comprehensive Cancer Network and American Urological Association renal cell carcinoma surveillance guidelines. J Clin Oncol. 2014; 32:4059-65. https://doi. org/10.1200/JCO.2014.56.5416. [PubMed]

5. Silvera D, Formenti SC, Schneider RJ. Translational control in cancer. Nat Rev Cancer. 2010; 10:254-66. https://doi. org/10.1038/nrc2824. [PubMed]

6. Truitt ML, Conn CS, Shi Z, Pang X, Tokuyasu T, Coady AM, Seo Y, Barna M, Ruggero D. Differential requirements for eIF4E dose in normal development and cancer. Cell. 2015; 162:59-71. https://doi.org/10.1016/j. cell.2015.05.049. [PubMed]

7. Cancer Genome Atlas Research Network. Comprehensive molecular characterization of clear cell renal cell carcinoma. Nature. 2013; 499:43-49. https://doi.org/10.1038/ nature12222. [PubMed]

8. Sato Y, Yoshizato T, Shiraishi Y, Maekawa S, Okuno Y, Kamura T, Shimamura T, Sato-Otsubo A, Nagae G, Suzuki H, Nagata Y, Yoshida K, Kon A, et al. Integrated molecular analysis of clear-cell renal cell carcinoma. Nat Genet. 2013; 45:860-67. https://doi.org/10.1038/ng.2699. [PubMed]

9. Bramham CR, Jensen KB, Proud CG. Tuning specific translation in cancer metastasis and synaptic memory: control at the MNK-eIF4E axis. Trends Biochem Sci. 2016; 41:847-58. https://doi.org/10.1016/j.tibs.2016.07.008. [PubMed]

10. Proud CG. Mnks, eIF4E phosphorylation and cancer. Biochim Biophys Acta. 2015; 1849:766-73. https://doi. org/10.1016/j.bbagrm.2014.10.003. [PubMed]

11. Brodaczewska KK, Szczylik C, Fiedorowicz M, Porta C, Czarnecka AM. Choosing the right cell line for renal cell cancer research. Mol Cancer. 2016; 15:83. https://doi. org/10.1186/s12943-016-0565-8. [PubMed]

12. Sinha R, Winer AG, Chevinsky M, Jakubowski C, Chen YB, Dong Y, Tickoo SK, Reuter VE, Russo P, Coleman JA, Sander C, Hsieh JJ, Hakimi AA. Analysis of renal cancer cell lines from two major resources enables genomicsguided cell line selection. Nat Commun. 2017; 8:15165. https://doi.org/10.1038/ncomms15165. [PubMed]

13. Oyarzabal J, Zarich N, Albarran MI, Palacios I, UrbanoCuadrado M, Mateos G, Reymundo I, Rabal O, Salgado A, Corrionero A, Fominaya J, Pastor J, Bischoff JR. Discovery 
of mitogen-activated protein kinase-interacting kinase 1 inhibitors by a comprehensive fragment-oriented virtual screening approach. J Med Chem. 2010; 53:6618-28. https://doi.org/10.1021/jm1005513. [PubMed]

14. Bain J, Plater L, Elliott M, Shpiro N, Hastie CJ, McLauchlan H, Klevernic I, Arthur JS, Alessi DR, Cohen P. The selectivity of protein kinase inhibitors: a further update. Biochem J. 2007; 408:297-315. https://doi.org/10.1042/ BJ20070797. [PubMed]

15. Campbell L, Jasani B, Griffiths DF, Gumbleton M. Phospho-4e-BP1 and eIF4E overexpression synergistically drives disease progression in clinically confined clear cell renal cell carcinoma. Am J Cancer Res. 2015; 5:2838-48. [PubMed]

16. Jolly MK, Somarelli JA, Sheth M, Biddle A, Tripathi SC, Armstrong AJ, Hanash SM, Bapat SA, Rangarajan A, Levine H. Hybrid epithelial/mesenchymal phenotypes promote metastasis and therapy resistance across carcinomas. Pharmacol Ther. 2019; 194:161-84. https:// doi.org/10.1016/j.pharmthera.2018.09.007. [

17. Martínez-Sáez E, Peg V, Ortega-Aznar A, Martínez-Ricarte F, Camacho J, Hernández-Losa J, Ferreres Piñas JC, Ramón Y Cajal S. peIF4E as an independent prognostic factor and a potential therapeutic target in diffuse infiltrating astrocytomas. Cancer Med. 2016; 5:2501-12. https://doi. org/10.1002/cam4.817. [PubMed]

18. Carter JH, Deddens JA, Spaulding NR 4th, Lucas D, Colligan BM, Lewis TG, Hawkins E, Jones J, Pemberton JO, Douglass LE, Graff JR. Phosphorylation of eIF4E serine 209 is associated with tumour progression and reduced survival in malignant melanoma. $\mathrm{Br} \mathrm{J}$ Cancer. 2016; 114:444-53. https://doi.org/10.1038/bjc.2015.450. [PubMed]

19. Yoshizawa A, Fukuoka J, Shimizu S, Shilo K, Franks TJ, Hewitt SM, Fujii T, Cordon-Cardo C, Jen J, Travis WD. Overexpression of phospho-eIF4E is associated with survival through AKT pathway in non-small cell lung cancer. Clin Cancer Res. 2010; 16:240-48. https://doi. org/10.1158/1078-0432.CCR-09-0986. [PubMed]

20. Adesso L, Calabretta S, Barbagallo F, Capurso G, Pilozzi E, Geremia R, Delle Fave G, Sette C. Gemcitabine triggers a pro-survival response in pancreatic cancer cells through activation of the MNK2/eIF4E pathway. Oncogene. 2013; 32:2848-57. https://doi.org/10.1038/onc.2012.306. [PubMed]

21. Furic L, Rong L, Larsson O, Koumakpayi IH, Yoshida K, Brueschke A, Petroulakis E, Robichaud N, Pollak M, Gaboury LA, Pandolfi PP, Saad F, Sonenberg N. eIF4E phosphorylation promotes tumorigenesis and is associated with prostate cancer progression. Proc Natl Acad Sci U S A. 2010; 107:14134-39. https://doi.org/10.1073/ pnas.1005320107. [PubMed]

22. Noske A, Lindenberg JL, Darb-Esfahani S, Weichert W, Buckendahl AC, Röske A, Sehouli J, Dietel M, Denkert C. Activation of $\mathrm{mTOR}$ in a subgroup of ovarian carcinomas: correlation with p-eIF-4E and prognosis. Oncol Rep. 2008; 20:1409-17. https://doi.org/10.3892/or_00000160. [PubMed]

23. Fan S, Ramalingam SS, Kauh J, Xu Z, Khuri FR, Sun SY. Phosphorylated eukaryotic translation initiation factor 4 (eIF4E) is elevated in human cancer tissues. Cancer Biol Ther. 2009; 8:1463-69. https://doi.org/10.4161/ cbt.8.15.8960. [PubMed]

24. Stead RL, Proud CG. Rapamycin enhances eIF4E phosphorylation by activating MAP kinase-interacting kinase 2a (Mnk2a). FEBS Lett. 2013; 587:2623-28. https:// doi.org/10.1016/j.febslet.2013.06.045. [PubMed]

25. Hu SI, Katz M, Chin S, Qi X, Cruz J, Ibebunjo C, Zhao $\mathrm{S}$, Chen A, Glass DJ. MNK2 inhibits eIF4G activation through a pathway involving serine-arginine-rich protein kinase in skeletal muscle. Sci Signal. 2012; 5:ra14. https:// doi.org/10.1126/scisignal.2002466. [PubMed]

26. Ichiyanagi $\mathrm{O}$, Naito $\mathrm{S}$, Ito $\mathrm{H}$, Kabasawa $\mathrm{T}$, Narisawa $\mathrm{T}$, Kanno H, Kurota Y, Kurokawa M, Fukuhara H, Sakurai T, Nishida H, Kato T, Yamakawa M, Tsuchiya N. Levels of 4EBP1/eIF4E activation in renal cell carcinoma could differentially predict its early and late recurrence. Clin Genitourin Cancer. 2018; 16:e1029-58. https://doi. org/10.1016/j.clgc.2018.06.002. [PubMed]

27. Piva F, Giulietti M, Santoni M, Occhipinti G, Scarpelli M, Lopez-Beltran A, Cheng L, Principato G, Montironi R. Epithelial to Mesenchymal Transition in Renal Cell Carcinoma: Implications for Cancer Therapy. Mol Diagn Ther. 2016; 20:111-17. https://doi.org/10.1007/s40291-0160192-5. [PubMed]

28. Kim HL, Seligson D, Liu X, Janzen N, Bui MH, Yu H, Shi T, Figlin RA, Horvath S, Belldegrun AS. Using protein expressions to predict survival in clear cell renal carcinoma. Clin Cancer Res. 2004; 10:5464-71. https://doi. org/10.1158/1078-0432.CCR-04-0488. [PubMed]

29. Lin H, Huang B, Wang H, Liu X, Hong Y, Qiu S, Zheng J. MTHFD2 Overexpression Predicts Poor Prognosis in Renal Cell Carcinoma and is Associated with Cell Proliferation and Vimentin-Modulated Migration and Invasion. Cell Physiol Biochem. 2018; 51:991-1000. https://doi. org/10.1159/000495402. [PubMed]

30. Moch H, Schraml P, Bubendorf L, Mirlacher M, Kononen J, Gasser T, Mihatsch MJ, Kallioniemi OP, Sauter G. Highthroughput tissue microarray analysis to evaluate genes uncovered by cDNA microarray screening in renal cell carcinoma. Am J Pathol. 1999; 154:981-86. https://doi. org/10.1016/S0002-9440(10)65349-7. [PubMed]

31. Ingels A, Hew M, Algaba F, de Boer OJ, van Moorselaar RJ, Horenblas S, Zondervan P, de la Rosette JJ, Pilar Laguna Pes M. Vimentin over-expression and carbonic anhydrase IX under-expression are independent predictors of recurrence, specific and overall survival in non-metastatic clear-cell renal carcinoma: a validation study. World J 
Urol. 2017; 35:81-87. https://doi.org/10.1007/s00345-0161854-y. [PubMed]

32. Kumar K, Chow CR, Ebine K, Arslan AD, Kwok B, Bentrem DJ, Eckerdt FD, Platanias LC, Munshi HG. Differential Regulation of ZEB1 and EMT by MAPKInteracting Protein Kinases (MNK) and eIF4E in Pancreatic Cancer. Mol Cancer Res. 2016; 14:216-27. https://doi. org/10.1158/1541-7786.MCR-15-0285. [PubMed]

33. Beggs JE, Tian S, Jones GG, Xie J, Iadevaia V, Jenei V, Thomas G, Proud CG. The MAP kinase-interacting kinases regulate cell migration, vimentin expression and eIF4E/ CYFIP1 binding. Biochem J. 2015; 467:63-76. https://doi. org/10.1042/BJ20141066. [PubMed]

34. Maimon A, Mogilevsky M, Shilo A, Golan-Gerstl R, Obiedat A, Ben-Hur V, Lebenthal-Loinger I, Stein I, Reich R, Beenstock J, Zehorai E, Andersen CL, Thorsen $\mathrm{K}$, et al. Mnk2 alternative splicing modulates the p38MAPK pathway and impacts Ras-induced transformation. Cell Rep. 2014; 7:501-13. https://doi.org/10.1016/j. celrep.2014.03.041. [PubMed]

35. Pinto-Díez C, García-Recio EM, Pérez-Morgado MI, García-Hernández M, Sanz-Criado L, Sacristán S, ToledoLobo MV, Pérez-Mies B, Esteban-Rodríguez I, Pascual A, Garcia-Villanueva M, Martínez-Jañez N, González VM, Martín ME. Increased expression of MNK1b, the spliced isoform of MNK1, predicts poor prognosis and is associated with triple-negative breast cancer. Oncotarget. 2018; 9:13501-16. https://doi.org/10.18632/oncotarget.24417. [PubMed]

36. Ueda T, Watanabe-Fukunaga R, Fukuyama H, Nagata S, Fukunaga R. Mnk2 and Mnk1 are essential for constitutive and inducible phosphorylation of eukaryotic initiation factor $4 \mathrm{E}$ but not for cell growth or development. Mol Cell Biol. 2004; 24:6539-49. https://doi.org/10.1128/ MCB.24.15.6539-6549.2004. [PubMed]

37. Ueda T, Sasaki M, Elia AJ, Chio II, Hamada K, Fukunaga R, Mak TW. Combined deficiency for MAP kinaseinteracting kinase 1 and 2 (Mnk1 and Mnk2) delays tumor development. Proc Natl Acad Sci U S A. 2010; 107:1398490. https://doi.org/10.1073/pnas.1008136107. [PubMed]
38. Campbell SC, Lane BR. Malignant renal tumors. In: Wein AJ, Kavoussi LR, Partin AW, Peters CA, editors. CampbellWalsh Urology. Philadelphia, PA, USA: Elsevier; 2016. pp. 1314-64.

39. Brannon AR, Reddy A, Seiler M, Arreola A, Moore DT, Pruthi RS, Wallen EM, Nielsen ME, Liu H, Nathanson KL, Ljungberg B, Zhao H, Brooks JD, et al. Molecular stratification of clear cell renal cell carcinoma by consensus clustering reveals distinct subtypes and survival patterns. Genes Cancer. 2010; 1:152-63. https://doi. org/10.1177/1947601909359929. [PubMed]

40. Verbiest A, Couchy G, Job S, Zucman-Rossi J, Caruana L, Lerut E, Oyen R, de Reyniès A, Laguerre B, Rioux-Leclercq N, Wozniak A, Joniau S, Van Poppel H, et al. Molecular subtypes of clear cell renal cell carcinoma are associated with outcome during pazopanib therapy in the metastatic setting. Clin Genitourin Cancer. 2018; 16:e605-12. https:// doi.org/10.1016/j.clgc.2017.10.017. [ [PubMed]

41. Gerlinger M, Horswell S, Larkin J, Rowan AJ, Salm MP, Varela I, Fisher R, McGranahan N, Matthews N, Santos CR, Martinez P, Phillimore B, Begum S, et al. Genomic architecture and evolution of clear cell renal cell carcinomas defined by multiregion sequencing. Nat Genet. 2014; 46:225-33. https://doi.org/10.1038/ng.2891. [PubMed]

42. Lopez-Beltran A, Scarpelli M, Montironi R, Kirkali Z. 2004 WHO classification of the renal tumors of the adults. Eur Urol. 2006; 49:798-805. https://doi.org/10.1016/j. eururo.2005.11.035. [PubMed]

43. Edge SB, Byrd DR, Compton CC, Fritz AG, Greene FL, Trotti A. AJCC cancer staging manual. New York: Springer; 2010.

44. Ito H, Ichiyanagi O, Naito S, Bilim VN, Tomita Y, Kato T, Nagaoka A, Tsuchiya N. GSK-3 directly regulates phospho-4EBP1 in renal cell carcinoma cell-line: an intrinsic subcellular mechanism for resistance to mTORC1 inhibition. BMC Cancer. 2016; 16:393. https://doi. org/10.1186/s12885-016-2418-7. [PubMed] 